IRA International Journal of Management \& Social Sciences ISSN 2455-2267

Vol. 14, Issue 02 (Special Issue) pg. 37-53.

International Conference on Wellbeing: Lifespan Perspectives $0^{\circ}$ Practices for Sustainable

Communities, 2019.

\title{
Environment and Wellbeing: Eco-psychiatry in Sundarban Delta, India
}

Dr Arabinda N Chowdhury, MD, Ph.D., FAMS, FRCPsych, Ph.D., D.Sc., Psychoanalyst

Consultant Psychiatrist, Leicestershire NHS Trust, UK and Visiting Professor, AGMC, Tripura, India.

Dr Arabinda Brahma, DNB, PhD.

Consultant Psychiatrist, Indian Psychoanalytical Society, Kolkata.

DOI: $10.21013 /$ jmss.v14.n2sp.p5

(c) Authors.

Type of Review: Peer Reviewed under the Responsibility of the conference's Scientific Committee.

Disclaimer: The copyright to this work is retained by the authorship. This work contains the opinions 6 views of the authorship solely and the same are not the views or opinions of the IRA. IRA disclaims of any harm or loss caused due to the published content to any party. 


\section{ABSTRACT}

Wellbeing is a multidimensional practical concept that captures a mix of people's life circumstances. Categorically wellbeing may be divided into three divisions: physical, mental and social wellbeing. As a construct, it may also be perceived as objective wellbeing (relates to material attributes like the amount of wealth, provision of education and health care and social infrastructure) and subjective wellbeing (how people think and feel about their quality of life). In both, the dimension Environment, more specifically the natural environment plays an important key role- both negative and positive. Convention on Biological Diversity (CBD), [1] postulates the ecosystem approach as a means of understanding the roles played by land, water and living resources of the environment (ecological resources) in the life of people as well as integrated management of cultural and biological diversity of the land and the people. Ecosystems are defined as the functional units that are in continual dynamic and complex interaction among plants, animals, water bodies, forest, climate and all other non-living issues in the environment. Ecosystem services are the benefits that people are supposed to or actually obtain from the ecosystem. These inter-phase interactional dynamics is the guiding principle of Ecopsychiatry - where environmental issues influence positively or negatively on the mental health of the people (individual) and the community (collective). Or in other words the impact of environmental specificity (of normal or abnormal state) on the mental health and wellbeing (as also physical and spiritual) of the community or individual. The Mellinium Ecosystem Assessment (MEA,) a major UN-sponsored project, offers a useful framework to explore these links. Four major MEA categories of Ecosystem Services are summarized in the following table.

\begin{tabular}{|c|c|c|}
\hline $\begin{array}{l}\text { Provisioning Service: Products } \\
\text { obtained from ecosystems }\end{array}$ & $\begin{array}{l}\text { Regulating Services: Benefits } \\
\text { obtained from the regulation of } \\
\text { ecosystem processes }\end{array}$ & $\begin{array}{l}\text { Cultural Services: Nonmaterial } \\
\text { benefits obtained from ecosystems }\end{array}$ \\
\hline - $\quad$ Food & - Climate regulation & - $\quad$ Spiritual \& Religious \\
\hline - $\quad$ Fresh Water & - $\quad$ Disease Regulation & - $\quad$ Recreation \& Ecotourism \\
\hline - $\quad$ Fuel wood & - Water Regulation & - $\quad$ Aesthetic \& Inspirational \\
\hline - $\quad$ Fiber & - Water Purification & - $\quad$ Educational \\
\hline - $\quad$ Biochemicals & - $\quad$ Pollination & - $\quad$ Sense of Place \\
\hline - Genetic Resources & & - $\quad$ Cultural Heritage \\
\hline \multicolumn{3}{|c|}{$\begin{array}{l}\text { Supporting Services: Services necessary for the production of all other ecosystem services. These processes allow the } \\
\text { Earth to sustain basic life forms, the whole ecosystems and people. Without supporting services, provisional, } \\
\text { regulating, and cultural services wouldn't exist. }\end{array}$} \\
\hline$\square$ Soil formation $\square \mathrm{Nu}$ & cycling $\square$ Primary production & osynthesis \\
\hline
\end{tabular}

It is a matter of great regret that in recent decades $60 \%$ of the world's ecosystems services are being degraded, destroyed and used unsustainably and thus presents a significant challenge and threat to maintaining the wellbeing of the current population and future generations [2]. The multifactorial degradation of ecosystem, nature or manmade, imbalances the stable relation between human and environment and thus risk their health and wellbeing. In the following discussion we put the case study as Sundarban Delta of India and try to enumerate the changing ecological equilibrium and different Ecopsychiatric problems and issues that risk the life of people, flora and fauna including the Royal Bengal tigers and the total mangrove landscape of the region- in other words, it makes the Sundarban as a "Delta of Distress".

Sundarban, India: Sundarban is the world's largest prograding delta at the basin of Bay of Bengal (Fig.1). It covers an area of $10,200 \mathrm{Km}^{2}$ of which $42 \%$ is in India and 58\% in Bangladesh. The forest extends over 200 islands, separated by 15 major rivers and 400 interconnected networks of tidal waterways that supports the largest tidal mangrove forest in the world. The Indian Sundarban comprises 19 community development blocks- 13 under South 24 Parganas and 6 under North 24 Parganas district of West Bengal state. UNESCO declared Sundarban National Park as World Heritage site in 1987 (Bangladesh Sundarban in 1997). Sundarban Biosphere Reserve, 9,630 Km², including $5400 \mathrm{Km}^{2}$ of the non-forest area, covers the delta south to Dampier-Hodges line and includes Sundarban Reserve forest, Tiger Reserve and human settlements. Sundarban is home to 56 species of reptiles, 250 species of 
fish, 220 species of birds and also the endangered Royal Bengal tiger. It is also an ecologically fragile and climatically vulnerable region that is home to over 4.5 million people.

The following inter-connected Eco-psychiatric issues that negatively impacted human wellbeing (both physical and mental) are discussed:

1. Anthropogenic factors and its impact on population density, land distribution, agricultural production, food insecurity and poverty.

2. Attempts to enhance the crop production in a climatic uncertainty and saline field by pesticide over/incorrect -use - resultant in a high incidence of mortality and morbidity (accidental and deliberate self-harm/suicide) of human and pesticide contamination of the environment.

3. Nutritional deficiency, animal health and livestock: salinization of water impacted the availability of freshwater fish species, and thus depriving the poor of their protein food source and adversely impacting the income and family integrity.

4. Risk factors in human-animal conflicts (tiger/ crocodile/snake attacks) and resultant mortality and morbidity: forest exploration for livelihood measures (fishing, timber-honey-crab-collection) leading to death, family disruption, poverty and overuse of eco-resources.

5. Sea-level change and its impact on environment and wellbeing: the health of human, animals, mangrove vegetation, repeated storm and flood, inundation of salt water in agricultural field (high salinity), flood and destruction of life and property is a recurrent event.

6. Land erosion and destruction of islands and internal and external migration and displacement of population.

7. Climate change and its impact on agriculture, food production, eco-resources and health and emergence of vector-born and water-borne diseases. Cyclone related disaster and it's public/ animal (tiger) health effects on the environment and population health.

Keywords: Sundarban, Eco-psychiatry, Mental Health and Wellbeing, Environment

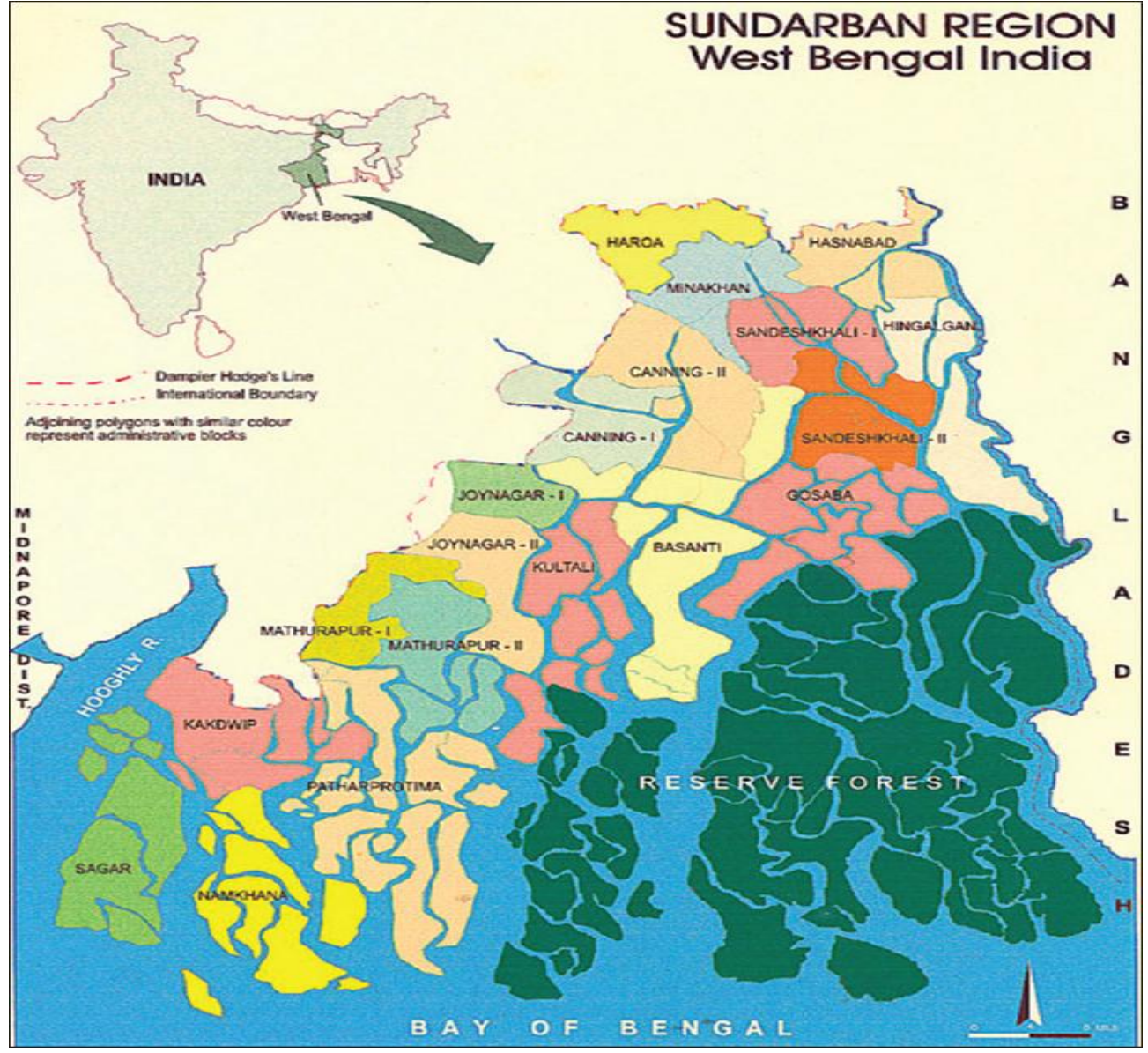

Fig. 1: Sundarban region, India (Not to scale) 
The following discussion will highlight the inter-relations among different eco-psychiatric risk factors in Sundarban that affect negatively the environment and vis-a-vis human mental wellbeing (and also physical). The different risk factors are summarized in the following risk-web distribution table (Fig 2).

Fig.2. ECOPSYCHIATRIC RISK-WEB AND ENVIRONMENTAL WELLBEING

\begin{tabular}{|c|c|c|c|c|}
\hline Demographic Risk & $\begin{array}{l}\text { Socio-Economic } \\
\text { Risk }\end{array}$ & Ecological Risk & Climatic Risk & Cultural Risk \\
\hline $\begin{array}{l}\text { Around the Impact } \\
\text { Zone: } \\
\text { Increasing } \\
\text { population pressure } \\
\text { Decreasing } \\
\text { agricultural land } \\
\text { and production } \\
\text { Pesticide calamity } \\
\text { Nuclear family }\end{array}$ & $\begin{array}{l}\text { No alternate } \\
\text { livelihood options } \\
\text { Poverty } \\
\text { Illiteracy } \\
\text { Lack of } \\
\text { Infrastructure } \\
\text { Geographical } \\
\text { remoteness \& } \\
\text { isolation } \\
\text { River Piracy }\end{array}$ & $\begin{array}{l}\text { Dependence on } \\
\text { Forest/River-based } \\
\text { living } \\
\text { Eco-depletion \& } \\
\text { Biodiversity loss } \\
\text { Encroachment of } \\
\text { Tiger habitat } \\
\text { (shark/crocodile } \\
\text { habitat) }\end{array}$ & $\begin{array}{l}\text { Sea-level change/ } \\
\text { Coastal erosion } \\
\text { Extreme weather } \\
\text { condition( cyclonic } \\
\text { storm), flooding, } \\
\text { changing the seasonal } \\
\text { pattern } \\
\text { Increased Water } \\
\text { salinity } \\
\text { Low-cropping } \\
\text { intensity/crop failure } \\
\text { Decrease prey-base/ } \\
\text { Tiger straying }\end{array}$ & $\begin{array}{l}\text { Cultural belief about } \\
\text { forest } \\
\text { Dependence on } \\
\text { Boulay/Moulay as } \\
\text { Protector } \\
\text { Spiritual conviction } \\
\text { on Bonobibi as } \\
\text { Saviour } \\
\text { Cultural interpretation } \\
\text { of Tiger attack } \\
\text { Eco-Tourism }\end{array}$ \\
\hline
\end{tabular}

\section{Demographic Risk: Cycle of unprecedented Population growth- land erosion and reduction-eco-specificity and crop failure - poverty and shifting livelihood - migration:}

During the post-independent period (1947 onwards) and especially after the Bangladesh War in 1972, this entire region has experienced a rapid influx of migrated population. In 1951 the area has population of 11,59,559, by 1991 rose to 32,05,552 and in 2011 census it crossed 40,00,000 (Fig 3). Deforestation and new human habitation exerted a negative impact on the local economy. Sundarban still remains an isolated, remote backward region of the state. The cumulative effect of all the following socio-political factors, viz. extreme population growth, low income level, lack of industries and employment opportunities, lack of electricity and organized transport, rain-dependent monocrop agriculture, raising of the river bed by man-made embankments, frequent cyclonic insult and inflow of tidal waves, make the people of Sundarban totally dependent on natural resources of the mangrove ecosystem at the risk of their life as well as of nature. The increasing population pressure not only pushed back the forest frontier but also competing for the resources with the wild animals and the invariable result is the violent human-animal conflict leading to loss of life on both sides. 


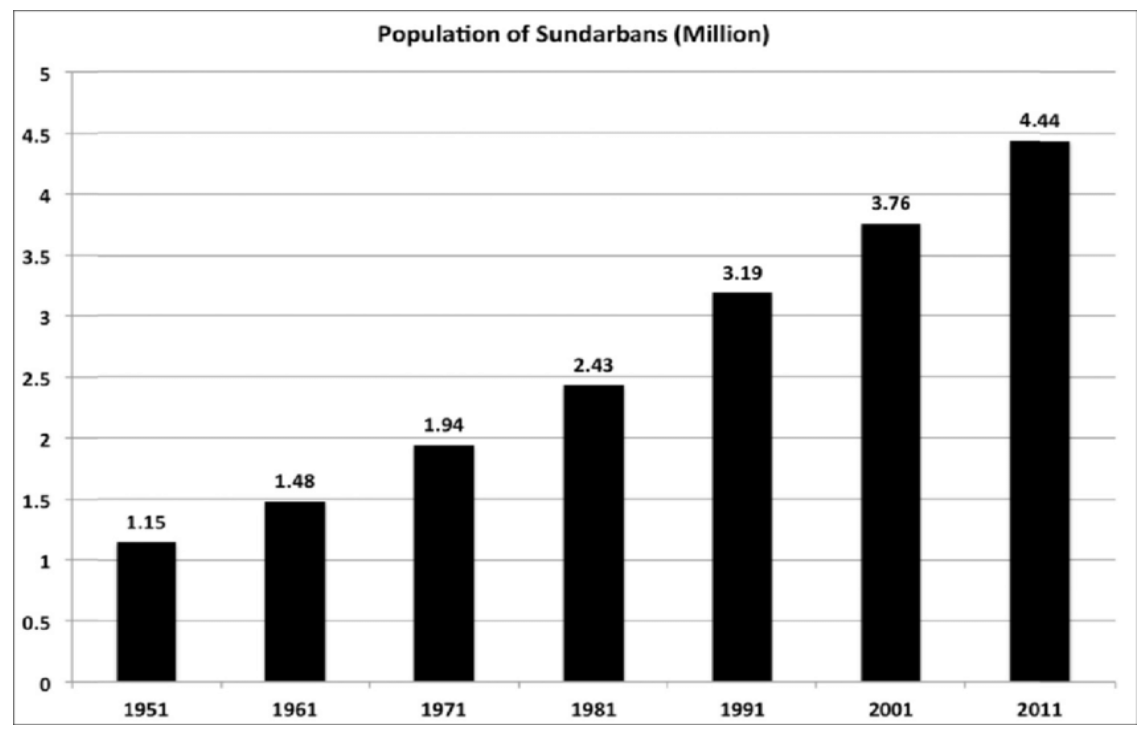

Fig 3. The increase of population over the decades in Sundarban. [3]

The availability of agricultural land shrunk from nearly $2,149.615 \mathrm{sq} \mathrm{km}$ to $1,691.246 \mathrm{sq} \mathrm{km}$ between 2002-2009. Ten islands of the Sundarban lost a total of $30.6 \mathrm{~km}^{2}$ land between 2001 and 2009. Currently, in 13 Sundarban blocks of South 24 Parganas, about $47.5 \%$ of households are landless and $41 \%$ own land measuring 1 acre or less. Only $64 \%$ of the agricultural land has some kind of groundwater-based irrigation support. It is shown that [4] that salinization, erosion, and inundation are the main reason of productivity losses that lead to extreme poverty, as poorest households experience the maximum material losses and that prompted the out-migration for a living. Around $34 \%$ of the 4.6 million people residing on different islands are under extreme poverty and among $75 \%$ of families there is at least one member working in other states of India- out-migration [5].

Unavailability of fresh water irrigation, high salinity of river water of up to 32ppt, soil salinity ranging between $2 \mathrm{dSm}-1$ to $19 \mathrm{dSm}-1$, are the serious constraints for agricultural production in Sundarban. It has been shown that the increasing population pressure on agriculture with an average Man-Cropland Ratio of 1745 person/ $/ \mathrm{km}^{2}$ In 20102011, the average cropping intensity was $129.97 \%$ and the irrigation intensity was $20.40 \%$ in Sundarban. It is estimated that [6] the annual agricultural water demand in Sundarban is $2784 \mathrm{mcm}$, but available water from 70000 freshwater tanks and around 8000 shallow tube-wells are not sufficient to meet this demand (of $382 \mathrm{mcm}$ during peak dry season), which seriously restricts the food production and food security of $87.5 \%$ of the people in Sundarban. There is a serious fall in production especially after the devastating Cyclone Aila: rice production was reduced to 32-40 quintal per 1.6 hectares from 64-80 quintal per 1.6 hectares produced before the disaster [7]. Cyclone Aila hit the Sundarban on May 25, 2009, and left 190 people dead and affected 3.8 million in India and Bangladesh. Over 2,40,000 houses were destroyed and 3,70,000 partially damaged. Persistent pressure from waterrelated threat is a serious issue [8] that affects both human and crop wellbeing [9].

Pesticide-related mortality and morbidity: In addition to soil quality degradation (salinity) and irrigation deficit, factors like excessive use of fertilizer and pesticide not only negatively impact the crop productivity [6] but also leads to a serious cause of farmers' morbidity and mortality (pesticide poisoning) [10] and environmental pesticidal pollution [11]. Overuse (often improper use) of different types of pesticides, extreme lack of knowledge of pesticide safety [12] is a rule rather than the exception in Sundarban. Government or WHO-pesticide/ILO prescribed safe custody of pesticide is meaningless because many of the farmers having only one thatched room which they share with their livestock's. Easy availability of pesticides facilitates impulsive suicidal behaviour among the vulnerable subjects [13]. Deliberate self-harm (DSH) by pesticide ingestion is a challenging public health problem in Sundarban. Yearly average DSH attempt is about 1800 (mostly young married women) and suicide 175 [14] in Sundarban region. Maximum cases are related to psychosocial problems, a few are with mental health diagnosis [15]. Accidental poisoning, especially among young children, is also very common [16]. Just to note a recent block hospital data (Namkhana) of a year showed 74 DSH cases (66 - 89.2\% survived and 8 - 10.8\% died) [17]. 
Pesticide contamination is also causing great damage to the environment. In the paddy field and local ditches all the fishes died, foxes in the bushes also died after eating pesticide poisoned fishes, grasses grow poorly and scanty and the cattle, goats are dwarf and are of weak health. An Ecotoxicological effect of pesticides changes the mangrove ecosystem's biogeochemistry and has an effect on other aquatic and terrestrial flora and fauna of Sundarban.

Change of living role and Eco-degradation: Limited earning prompts the farmers to look for other livelihood options, most important of which is the natural resource exploitation. Many farmers are forced to sell their lands and turned into daily labourers [11]. Census figures show that the numbers of cultivators are decreasing in Sundarban [18]. So over the years for multiple eco-specific and climate change factors, the main farmers of Sundarban have been converted into marginal workers. So the quality of life of the people is deteriorating and gradually they are losing their identity as a farmer and live with constant poverty, food insecurity and geographical vulnerability [19], which geared up a large out-migration from every Sundarban blocks.

\section{Social Risk: Less developed infrastructure- No alternative livelihood measures - Geographical remoteness - Illiteracy-Deficient access to health care-health-related superstition and stigma related to mental illness- river piracy.}

Sundarban is one of the poorest and highest population density regions of South Asia, with an estimated more than eight million people (India and Bangladesh combined) dependent on its fragile ecosystem. The population of Sundarban is heterogeneous, with a high influx of immigration from other parts of India and Bangladesh. This unprecedented population growth in the region has not only reduced the amount of per capita cultivable land but has also created both overcrowding and high rates of unemployment. The subdivision and fragmentation of landholding either through property division or climatic destruction (land erosion), the landed households have gradually turned marginal and were no longer able to be sustained through agriculture alone. As a consequence of this, fishing and other forest-based living have become the main occupation for these islanders, leading to further eco-resource depletion.

The people of Sundarban live in an ecologically vulnerable environment. The area is prone to cyclones, and often super-cyclones [20]. It is monsoonal and low-lying with many human settlements located alongside the waterways and coastline. The man-made river embankment $(3,500 \mathrm{~km})$ serves both as a flood defence wall and also to protect the agricultural land and human settlements from diurnal tidal surges. The mean tidal amplitude of Sundarban region is between $5.22 \mathrm{~mm}$ and $3.14 \mathrm{~mm} / \mathrm{year}$, which are much higher than the national average of $1.06-1.75 \mathrm{~mm} /$ year [21]. The embankment built to hold these tides back frequently ruptures and pushes saline water on to the agricultural land, causing serious damage to crops, property, and the lives of inhabitants, often leading to internal displacement, social vulnerabilities, and livelihood crisis [22].

Hindus are the predominant religious group in the region, followed by Muslims, and 36.5\% of the population belongs to scheduled caste and tribe. Seventy-eight per cent of the economy and $65 \%$ of workers are dependent on agriculture. A high per centage of landless agricultural labourers substantiates the level of poverty in the region. It has exerted a negative impact on the economy of the fringe population as well. About $52.3 \%$ of workers in agriculture and fishing are daily-wage labourers. Agriculture is hard and risky work with low cropping intensity because of the high soil salinity and irrigation constraints (only 12\% cultivable land is irrigated), frequent seasonal variations, and climatic incidents resulting in crop failure [23, 24]. During the agricultural lean season, more people resort to forest-based livelihood activities (fishing and collection of prawn seeds and honey) and subsequently risking their lives to man-eating tigers, crocodiles, and sharks. Low prey-density and physical disability also encourage tigers to stray into the fringe villages, which precipitates both livestock killing and human-tiger conflicts.

Sundarban then is a severely underdeveloped region with a very poor quality of life for its inhabitants [25]. Forty per cent of the population of South 24 Parganas district lives within the boundary of the Sundarban Biosphere Reserve. Population density has increased from 934 per km${ }^{2}$ in 2001 to 1,082 per km$~^{2}$ in 2011 . The population of Sundarban, especially those of the island blocks around forests (Gosaba, Basanti, Kultoli, Patharpratima, and Namkhana), are also, when considered against the Human Development Index, the most backward in terms of most of the components of the Index ( 0.55 in contrast to 0.62 of the district). The stark underdevelopment of Sundarban is also further reflected in the facts that $44 \%$ of the population is living below the poverty line (BPL) and $87 \%$ of the people suffer food insecurity, $60 \%$ households have no access to safe drinking water, $70 \%$ of the families live in thatched mud houses, and $47.6 \%$ of household have no land. According to a 2014 World Bank report: A fifth of the 
population gets only one meal a day and for a third of them, it is a sub-standard one. Half the children suffer from malnutrition. Poor environmental conditions cause 3,800 premature deaths and 1.9 million cases of illness every year, primarily among children and adult women. In one block (Patharpratima) the overall prevalence of anaemia studied in women was as high as $64 \%$. The level of literacy (77.1\% state, .35\% in Sundarban) and per capita income of the Sundarban resident is accordingly much below the state average. Rural Household Survey showed that in South 24 Parganas district more than 400,000 households are BPL and thus making the poverty ratio (\% of household) to $34.11 \%$, which is far above the state as well as national poverty ratio [26].

The infrastructural facilities are extremely poor, there is no industry, the communication and transport networks are very poor, and electricity is almost nonexistent in this region (only 17\% of households have grid connectivity). Health care is poor and inadequate [27], and nearly $33 \%$ of the population do not even have access to primary health care. There is an extensive network of health care providers (HCPs -unregistered health care providers- locally known as 'Quacks) and Sarpa-Baisya (healers for snake bite) and other traditional healers like Ojha, Gunin, Fakir throughout the islands and they provide the first line of clinical contact in any illness or distress, ranging from physical to mental illness tor ghost possession or epilepsy. Magico-religious faith is highly prevalent among the islanders and thus rituals relating to Bonobibi or Ma-Monosa puja are considered as therapeutic methods in any illness [28].

For all these reasons outlined above, the dependence therefore of the fringe population in Sundarban on ecoresources is high. Of the 4.1 million people live in Sundarban, 32\% depend on the resources of Sundarban mangrove forest directly or indirectly.

River piracy is a threat to life and property: River pirates are causing a major threat to the fishing communities of Sundarban. More than 50\% of the population of Sundarban is dependent on fishing for their livelihood. During the fishing season, nearly 60,000 fishermen go out every day to high sea for fishing. In addition to the dangers of climatic insult and wild animal attacks (tiger and crocodile), they also face attacks from pirates, who sometimes capture their trawlers and boats, seize their catch and hold them hostage. The ransom money they demand ranges from Rs. 30,000 to 1 lakh. There are incidents reported where the pirates even killed their captives when their demands were not met [29]. Piracy is concentrated at the mouth of the Matla, the Bidya and the Thakuran rivers, near the Bay of Bengal. There are reports of several abductions of fishing trawlers and demand of high ransom money, especially during Hilsha-season. It is reported that pirates are also engaged in smuggling of arms consignments. Though the river piracy in Sundarban is a monopoly of Indian pirates but frequently in the bay region foreign-pirate vessels are active. The $70 \mathrm{~km}$ riverine border between India and Bangladesh has practically no checkpoint or Border Security Force outpost. This makes trans-border piracy all the more easy. Most of the piracy is carried out by local gangs but there is a network of gangs from Bangladesh, Myanmar and Thailand. The remote Sundarban islands are also exposed to criminal gangs from the other side of the border and have made loot and kidnapping for ransom in the community [30].

\section{Ecological risk: Dependence on Forest/River-based living- Eco-depletion \& Biodiversity loss- Destruction of Mangrove shield - Encroachment of Tiger/Crocodile habitat:}

The main forest-based livings for people of Sundarban are:

1. Fisherfolk. Micro-fishing (catching fishes in creeks and rivers) and macro-fishing (in the sea) are the main livelihood activities for communities living in the fringe area of the forest and also along the coastal line, respectively. A total of 478,770 people fish in the Sundarban including in the adjacent Bay of Bengal, of which 144,171 people are active fishers living in 282 fishing villages. Around 2,069 $\mathrm{km}^{2}$ of the water tracks inside the Sundarban Reserve Forest (SRF) are used for river fishing, using traditional methods. Fishing is always accompanied by occupational dangers, either from tiger or crocodile attack or from climatic events [31].

2. Wood cutters and firewood (Golpatta - Nipa fruticans and Hental - Phoenix paludosa) collectors. The annual average timber collection from SRF is about 120,000 quintals. Approximately 5\% of the population is involved in wood collection; usually, a team of 6-10 wood cutters are lead by a Boulay into the forest. A Boulay is a man with traditional expertise, one who knows the art of keeping the team out of danger in the forest; they are also believed to have supernatural powers to protect the work area so that tiger cannot enter into this enchanted territory [32]. 
3. Honey collectors. (from the beehives of Apis indica). This is a seasonal group activity. Usually a team of 8-10 members is lead by a Moulay into the forest. Moulays are those indigenous people known for their traditional wisdom and expertise. As with the Boulay, the Moulay is also believed to possess supernatural powers to prevent tiger attacks by their rituals and chants [33]. Honey collection is highly dangerous as it takes place directly in the tiger habitat. About $3 \%$ of the population is involved in this activity, and on an average, 200 quintals of honey and $1,000 \mathrm{~kg}$ of wax are collected annually [34].

4. Crab collectors. The estuarine mud crab Scylla serrata (mangrove crab) is an edible species distributed across the mudflats of the Sundarban forest and has a good market demand, both locally and internationally [35]. The crab collectors are often taken by tigers when they are concentrating on their catch [36].

5. Shell collectors. Snails, clams, and giant oysters are distributed around the forest floor and mud flats. These mollusks are also of ecological importance to the mangrove in converting leaf litter into detritus. Their shells are used by people for preparing lime, shrimp, and chicken feed.

6. Tiger prawn seed collectors. This mainly involves women and children. One survey [37] of 3,252 tiger prawn seed (TPS) collectors in 1,917 households among 11 Sundarban villages showed that $74 \%$ of collectors were female while $26 \%$ were male. They collect prawn seeds from brackish water for a lucrative on-the-spot earning of about Rs. 50-100 (USD \$ 1-1.5) per day per person. The collection of juvenile prawns has become a major income source with estimates of up to 200,000 collectors involved within the Sundarban. It is now estimated that 1,500-3,000 million prawn seeds are collected annually, feeding a large demand for prawn seeds from the neighbouring shrimp aquaculture industry. The extensive TPS collection for the corporate business network has created an ecological disaster in the region and has resulted in the severe depletion of local shrimp and other fish populations [38]. The seed collectors are prone to a shark (Indian dog shark, Scoliodon laticaudus, locally called Kamote) and crocodile (Crocodylus porosus) attacks. TPS collection near or inside the SRF also carries a high risk of a tiger attack.

The Sundarban authority issues over 3,700 Boat License Certificates and seasonal passes to individuals, allowing them entry into the forest for a permitted activity in a designated area. Illegal trips into the forest are locally called as Black trips. On average, over 10,000 villagers will enter the forest each year clandestinely for their living. Their deaths go unreported because any forest entry without permission is a criminal offense and subject to penalty and legal proceedings. On a legal trip, if death results from a tiger attack (outside the core area), the family is supposed to receive some compensation from the Forest Department.

Traditional livelihood measures (timber, fuel wood and honey collection) and fishing and tiger prawn seed or crab collection in river bank - is the cause of recurrent human-animal conflicts (tiger, crocodile, shark, snake) [39, 40]. The average yearly death toll from tiger attack is 15 , crocodile or shark attack 10 , snake bit nearly 100 . This is huge morbidity and mortality in Sundarban because of the eco-vulnerability of the region.

Over-exploitation of forest goods: Fishery and collection of non-timber forest produce heavily impacted rampant deforestation and overfishing has put the environment under tremendous pressure. Fish stock is dwindling, fish density in shallow waters has reduced and the catch of commercially important fish has declined. The increased local demand for prawn products has led to the local population to abandon sustainable traditional fishing practices and adopt excessive prawn seed culture. This has led to serious harm to the environment due to the erosion of the mangrove eco-system [41].

Health impact: The eco specificity of Sundarban predisposed a heavy toll on both physical and mental health of this island population. The pesticide is the causal agent for an enormous number of casualty, survivors families are in acute mental health need, forest exploration is a part of livelihood and so the casualty from human-animal attacks continues, leading to an accumulation of a considerable number of tiger-widows in every village. They are living in a segregated cluster, called 'widow-hamlet' with indescribable physical and mental sufferings [42,]. Many of the survivors of tiger and crocodile attack in addition to physical disability and disfigurement also having to disable Post-Traumatic Stress Disorder [43]. Readymade cash from tiger prawn seed collection mostly helps the spread of excessive alcohol use [44] in the region. 
IV. Climatic Risk : Sea-level change/ Coastal erosion- Extreme weather condition (cyclonic storm), flooding, changing seasonal pattern- Increased soil salinity-Low-cropping intensity/Pesticide pollution/ deforestation Decrease prey-base/ Tiger straying

Sundarban is facing serious challenges due to climate change which has severely affected human survival as well as the biological diversity of the region. Following are the few [45] salient effects and impact of climate change:

A. Increasing sea water temperatures: Recent research showed that between 1980 and 2007, the temperature of the waters in the Sundarban has increased at an accelerated rate of $0.5 \mathrm{oC}$ per decade compared to the observed global sea surface temperature warming at the rate of $0.06 \mathrm{oC}$ per decade. This increased temperature negatively impacted the aquatic marine life and the mangrove ecosystem.

B. Rising sea-levels: Since the last 25 years the sea level has raised at a rate almost double the global average. This is leading to submerging of low-lying coastal land mass and heavily damages the mangrove photosynthesis and consequent regeneration of new groves. Of the 102 low-lying islands in the delta, about 48 are inhabited by nearly 4 million people. In the past 20 years, four islands (Bedford, Lohachara, Kabasgadi and Suparibhanga) were submerged and displaced 6,000 families. Up to a dozen islands, home to 70,000 people, are immediately threatened by the rising seas inundating homes and livelihoods. The report estimates that one million people will become climate change-refugees by 2050 and around 1.5 million people will be displaced in the Sundarbans, and the process has already been started [46].

C. Cyclonic storms: It is reported that the intensity and frequency of cyclones hitting Sundaraban have increased considerably between 1951 and 2010. Recently by the Cyclone Aila (2009), $400 \mathrm{~km}$ of the embankment was breached and more than 2 million people were marooned and extensive farmland became salinised and nonproductive and huge damage of property and live stocks compelled people to immigrate to the nearby urban cities.

D. Soil Salinity and agricultural crisis: The decrease in fresh water runoff in Sundarban rivers, the salinity has increased which not only affected mangrove growth but also causes severe crop failure and deceased crop production. The salinity of the agricultural fields is also caused by high tides, cyclones and storm surges, prolonged water stagnation and inundation by salt water due to rupture of embankment barrier. Soil erosion, climatic insults, frequent pest attacks and deficient irrigation are the causes of agricultural failure and consequent debt and depression of the farmers, which often leads to suicides and chronic mental and physical ill health.

E. Deforestation: It is estimated that $5.5 \%$ of forest cover was lost between $1986\left(2,246.839 \mathrm{Km}^{2}\right)$ and 2012 $\left(2122.421 \mathrm{Km}^{2}\right)$ [47]. This deforestation has increased man-animal conflict, local extirpation of several species and bio-diversity loss of the region.

F. Pollution: Sundarban Rivers are highly polluted with domestic and industrial effluents, heavy metals from Haldia port complex and organochlorine pesticides and agricultural wastes. All these have altered dangerously the estuary's geochemistry and impacted the diverse aquatic biodiversity and the coastal eco-environment of Sundarban. Pesticides enter the food chain and insecticides eliminate the fish and crab population. Herbicides kill the two key pollinators in Sundarban forest- the Giant Honey Bee and Crow butterflies.

G. Increase in man-animal conflict: One study [48] predicted that the climate change effects in the Sundarbans mangrove forest through changing its biodiversity composition in terms of loss of wildlife habitats may accelerate tiger-human conflicts. Another study [49] reported that the number of tiger attacks on people is growing in Sundarban islands as habitat loss and dwindling prey caused by climate change drives them to prowl into villages for food. The annual mean frequency of tiger straying is 15.8 during the period 2002-2009.

H. Spread of Diseases: Climate change will have significant effects on wildlife, domestic animal, and human diseases, especially zoonotic diseases (diseases that are transmissible between animals and humans) [50]. Due to atmospheric temperature and humidity variation, the wildlife host-pathogen interactions will be modified and this also affects marine ecosystem. Water stagnation and infection may cause a greater risk of water-borne diseases among humans. 
I. Climate change and mental health: Climate change will affect mental health directly by exposing people to trauma and devastation and indirectly by affecting physical health and community wellbeing (by eroding physical and socio-economic environment). It may lead to increased suicide mortality also [51]. Climate change has wideranging impacts upon human health and well-being, through changes and challenges to people's environment, socioeconomic structures and physical security and community damage and disconnectedness [52].

WWF [53] in their climatic adaptation report of Sundarban stressed at least four factors that heavily impact the Sundarban's ecology: 1. Environmental factors affecting farming; 2. Environmental factors affecting fishing; 3 . Sea level change and coastal erosion and 4. Change in high-intensity events like storms and cyclone.

\section{Cultural risk: Cultural belief about forest- Dependence on Boulay/Moulay as Protector-Spiritual conviction on Bonobibi as Savior -Cultural interpretation of Tiger attack and related stigma}

Bonobibi and the Tiger God. The people of Sundarban, both Hindus and Muslims together, have a strong faith in the folk cult of Bonobibi (the Queen of the forest), (Fig. 4) as the guardian deity of the forest together with the Tiger God under the name Dakkhin Ray (Lord of the South). Sundraban islanders perceive Bonobibi as the unified symbol of the forest and the people, and she stands beyond any caste, class, and religion [54]. Before entering the forest for fishing, harvesting honey, or wood cutting, it is obligatory to offer puja and pray to the Deity asking to keep them protected from tigers. Invocation of the Tiger God is also a mandatory ritual for safe passage throughout the Sundarban forest territory.

Manasa. Manasa is the cult Hindu folk Goddess of snakes and protector from snake bites, and in almost every home in Sundarban, there can be found a sacred altar with a Manasa shrub (a Sij plant of a cactus family Euphorbia genus). The health burden (both mortality and morbidity) caused by snake bites, both poisonous and nonpoisonous, is high in Sundarban. People will usually prefer traditional treatments from the magico-religious healers than antivenom treatment at the health centers. The people of Sundarban have deep faith in these folk deities to keep them safe and order their lives, and this is reflected in their day-to-day cultural rituals and social discourses [55].

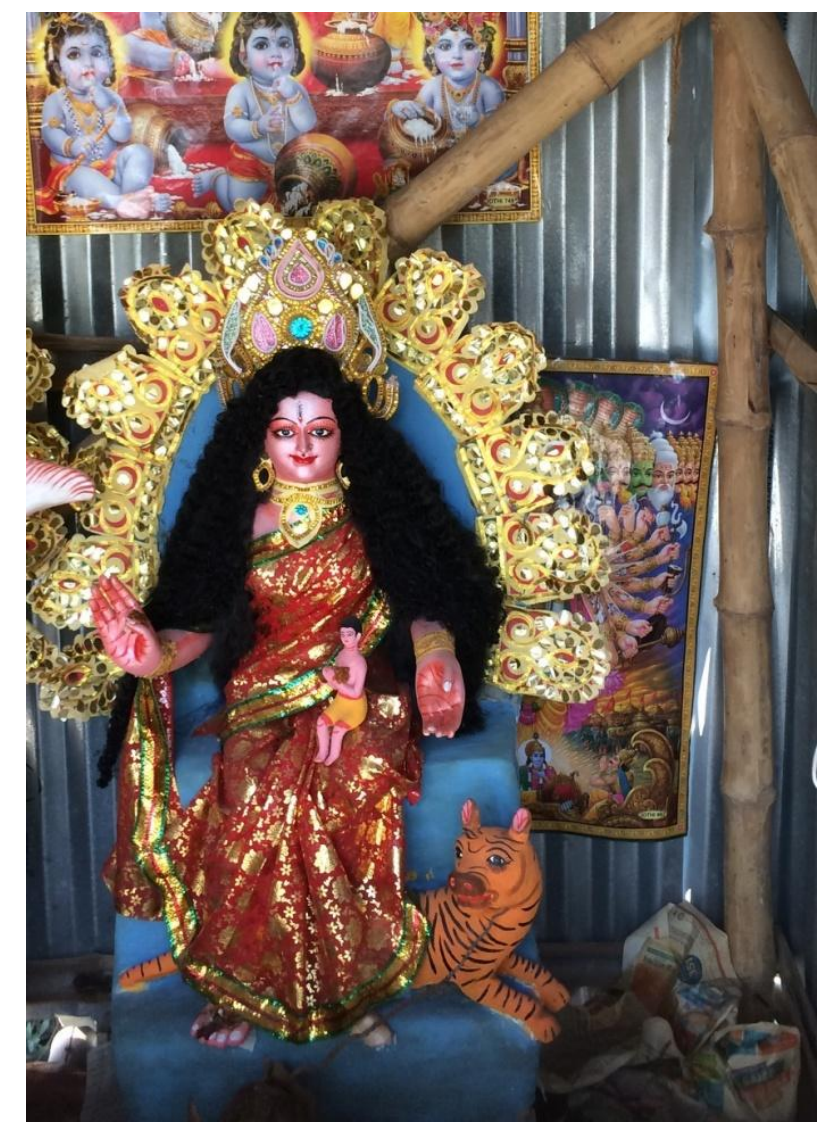

Fig.4. Bonobibi idol at the entrance of SRF at Jhorkhali, Basanti block. 
Stigma and discrimination related with Tiger attack: Chowdhury et al [56] in their study by using a measurement of stigma showed that the Tiger-widows are more stigmatized than both normal and snake-bite widows. It is interesting to note that in cases of tiger-widows (in contrast to other widows), a social belief and superstition relating to tiger attack/killing is operative as a strong determinant of stigma. Stigma develops by a twofold process at the backdrop of local culture. The first component is a deep belief and religion-spiritual faith in the cult of Bonobibi and the Tiger God and the second is its extension as a behavioural reflection in the form of the labelling, blaming, and the consequent discrimination of tiger-widows by family and the community at large. As an extension of this belief, and as a result of the illiteracy and superstition, many natural and normal forest or community incidents or events act as a cultural reinforcer to the belief of divine disgrace, which in turn, cumulatively adds to the strength of cultural stigma about being killed by a tiger.

The spiritual dimension of a tiger attack. The concept of the forest is a key element in the worldview of the Sundarban islanders. They believe that badabon (the Mangrove forest) is a sacred entity - a gift from God, the abode of the Goddess Bonobibi and the reservoir of their food and woods which are so vital for their survival. All community life in these remote disconnected, poverty-stricken islands, including rituals, customs, and psychological make-up, livelihood resources, and the forest, are interblended into a matrix of ecology, culture, and spirituality. These interactions have generated a socially accepted context of myth and supernaturalism that directs their existential worldview and value system. [57] This has helped to develop an environmental culture where they acknowledge their destiny with a mix of grace and threat centering around the dense and mysterious forest and the tidal rivers in which they live. Symbolically, the forest stands as eco-mother; as one woodcutter said: "We live on forest, we should always pay reverence to Ma (Bonobibi) and the Borothakur (Tiger) in any forest activities; they will definitely keep us safe". This belief is deeply ingrained in their social and cultural life [58]. The cult of Bonobibi and the Tiger God Dakkhin Ray [59] offer a strong psychological defense and dependence to overcome the daily struggle with life in the difficult terrain of Sundarban.

\section{Tourism - a new dimension of threat to Sundarban?}

The natural beauty of mangrove forest and meandering creeks and varieties of wild lives including the Royal Bengal tigers is a great attraction of tourists to visit Sundarban forest. So the number of tourist is increasing over the years. Different private tour operators (at least a dozen) arrange different tour packages in the Sundarban to expose the visitors to Sundarban's unique eco-diversity. It is noted that the tour operators are not aware of the forest conservation issues due to lack of training or awareness program. One study [60] shows that in 2008 there were approximately 1 Lakh tourists visited Sundarban of which 96000 were Indian tourist and 4000 were foreign tourists.

The International Ecotourism Society [61] defined Ecotourism as "responsible travel to natural areas that conserves the environment and improves the well-being of local people". Ecotourism is productive interphase among conservation, communities, and sustainable travel. So the main objective of any eco-tourism should be [62]: 1. Minimize the impact on ecological balance. 2. Build environmental and cultural awareness and respect. 3. Provide positive experiences for both visitors and hosts. 4. Provide direct financial benefits for conservation. 5. Provide financial benefits and empowerment for local people and communities. 6. Raise awareness and sensitivity on the conservation of bio-diversity in the political, environmental, and social climate of the country.

In view of these principles, we can examine how far the ecotourism attempt at Sundarban is really successful or more specifically what are the negative and positive effects of tourism on the life and environment of Sundarban. Though eco-tourism is said to be a potentially emerging economy for conservation and pro-people [63] but evidence from the recent analysis showed very disturbing picture. It is said that "Tourism pollution" as one of the major threats to Sundarban ecosystems [64].

Following are the few potential negative impacts of Eco-tourism (tourist infrastructure and tourist activities) in Sundarban:

1. Straining Water resources and quality. 2. Air quality (from transport emissions and emission from energy production). 3. Habitat or Ecosystem alteration and fragmentation (by tourist infrastructure, tourist activities, tourist boats and cruise can damage and pollute aquatic vegetation). 4. Impacts on wildlife. 5. Uncontrolled growth of 
tourism may be a major cause of degradation of the environment and loss of local identity and aesthetic value of traditional cultures.

Some Positive impacts of Eco-tourism are:

1. An opportunity for economic development, economic diversification and the growth of related activities. 2. Has the potential to increase public appreciation of the environment and to generate environmental awareness that may lead to environmentally conscious behavior and activities to preserve the environment.

\section{Recent research findings:}

Recent research [64] noted that the "impacts resulting from tourists visiting the area and the lack of control placed on their behaviour within the park". They stressed the "need for adoption of appropriate management activities through awareness and education of local communities, regulatory bodies and tourists in and around the National park area".

One study [65] made a comparison between tourism-participated and non-participated villages in a block of Sundarban (Gosaba). They found that:

1. Participant households spend $19 \%$ more on food and $38 \%$ more on non-food items per capita relative to similar non-participants. Thus, tourism as a poverty reduction strategy may be useful. 2. Most of the villagers feel that the spread of tourism has improved transport and telecommunication, road conditions, and ferry services, as well as helped spread the Sundarban's local cultural heritage and folk art into the outside world. 3. Most of them are also of the opinion that tourism at its present scale does not significantly reduce the forest dependence of locals. 4 . Tourism has resulted in increased income inequality in the village. 5. Tourism does not contribute to problems such as reduction in drinking water, pollution and congestion or increased crime. 6. The unequal distribution of tourismrevenue in the study village, and the uneven interactions of locals with visiting tourists was an issue. 7. Households were divided in their opinion on a number of issues such as the increase in land and agricultural and other product prices as a result of tourism; the cultural 'shock' effects of tourism and the impact of tourism and income inequalities on their own community lives.

The study made few important recommendations: 1. The number of local jobs that result from tourism needs to grow. 2. Lack of infrastructural facilities, most notably electricity, should be improved. 3. Tourists are usually availed package-tours originating in far-off places which provide little scope for locals to enter into trade with the visitors. 4. There should be more publicity and information dissemination is required about the Sundarban. New vistas should be explored such as nature-based tourism with products like forest-walks, tree-top houses, etc.

An in-depth study [60] of Eco-tourism in Sundarban concluded the following need: 1. Proper ecotourism package development involving local people in decision making and planning so that there is a larger involvement of the community. 2. Diversification of ecotourism products like stay in country boats, trail walks etc. which will help in retaining the majority of the income generated with the local people. Among the negative impacts, the study mentioned about: 1. Low involvement of local people in tourism and little incentive for the local people from tourism in terms of income generation. 2. Potential negative environmental impacts (damage to mangrove vegetation). 3 Pollution by sewage, dumping of the wastes in the river. 4 . Increase in biotic pressure due to increase in mass tourism.

The present authors in a focus group discussion on the role of tourism in the life of people of Sundarban held at Pakhirala village (2016), Gosaba, found these comments:

1. There are some job opportunities for local people but some are menial jobs and to wash the toilets are very derogatory for the woman folk of the villages. 2. The remuneration for labour job (like guard, helper, boatman) is too meagre. 3. The recruitment procedures are not very transparent so it causes an undue hostility and jealousy among the villagers. 4. Tourists from Kolkata and their behaviour and wealthy dress and proud nature often create a new world of envy among this distant island village. Instead of a cultural mix, it creates cultural stress among local inhabitants. 5. Alcohol use within the tourist lodge causes some problems. 6. Disposal of plastic bags, bottles and 
rubbish are a constant nuisance. 7. Noise pollution from high pitch loud-speaker from the river-bank picnic spot is often quite disturbing.

Eco-tourism should encourage environmental conservation along with strengthening of human wellbeing, identity and cultural values. Following is the interactions of different issues in the matrix of human-environment-culture dimension [adapted from 66]:

\begin{tabular}{|l|l|l|}
\hline \multicolumn{2}{|c|}{ Human Wellbeing- Environment-Cultural interrelation } \\
\hline Intangible & Tangible & Mixed \\
\hline Quality of life and wellbeing & Riverine fishing & Local cultural heritage \\
\hline Spiritual connectedness & Farming & Folk Music and dance \\
\hline Community cohesiveness & Wood cutting & Myth about forest \\
\hline Social values and identity & Honey collection & $\begin{array}{l}\text { The myth about disease and } \\
\text { health }\end{array}$ \\
\hline Traditional knowledge & Cultural landscape & Traditional healing \\
\hline Connection with forest & Religious festivals & Medical plants \\
\hline
\end{tabular}

It is suggested [67] that a practical national policy with an integrated plan and strengthening of technical and financial capacities of the tour operators is essential to develop a pro-people eco-tourism in Sundarban. This approach may consider imposing conservation tax, definite community participation in each step and strengthening of local micro-enterprises to achieve the goal of ecotourism and conservation. Local economy boost should be a priority.

\section{Conclusion:}

It is evident from the ecological risk-web analysis that not only the mental health of Sundarban population but their mere survival is always under the different spectrum of high threat and uncertainty. Factors related to the ecospecificity of the region are responsible for these risk factors as well as the anthropogenic factors are also operative in the destruction of eco-resources and bio-diversity of the region. It also shows how the eco-system goods and services are exhausted and threatened by depletion of eco-resources and inviting a serious eco-crisis that affects physical, mental and social wellbeing of the individual and the community. Fig. 5 shows this ever increasing interrelationship of eco-stress and human well-being in Sundarban. For both, human wellbeing and tiger-bioconservation, serious consideration should be paid to local socio-cultural factors by stakeholder engagement in participatory decision-making and planning and that may enhance the conservation attempts [68]. Proper policy protocol development, alternative livelihood provision, poverty reduction with realistic conservation management strategies with community involvement and political will may mitigate a portion of these risk- threats and help to build a sound population with a balanced physical and mental wellbeing in a prosperous eco-landscape. No human wellbeing will be achieved without the wellbeing of the environment. 
Fig 5. The interrelationship of agricultural eco-stress, ecosystem damage and human wellbeing.

\begin{tabular}{|c|c|c|}
\hline $\begin{array}{l}\text { Agriculture } \\
\text { Ecological Influences: } \\
\text { Increasing population } \\
\text { and decreasing land } \\
\text { High salinity and low } \\
\text { production } \\
\text { Rain-dependent } \\
\text { mono-crop } \\
\text { Frequent climatic } \\
\text { insult- rain, } \\
\text { drought, tidal inflow } \\
\text { Frequent crop-failure } \\
\text { Over-use/wrong-use of } \\
\text { pesticides- uncontrolled } \\
\text { pesticide market- easy } \\
\text { availability of pesticides } \\
\text { Continued economic } \\
\text { stress and poverty } \\
\text { More people are leaning } \\
\text { to Traditional Livelihood } \\
\text { Measures for survival } \rightarrow\end{array}$ & $\begin{array}{l}\text { Traditional } \\
\text { Livelihood } \\
\text { Measures } \\
\text { Forest/river } \\
\text { based eco- } \\
\text { depleting } \\
\text { activities: } \\
\\
\text { Fishing } \\
\text { Wood Cutting } \\
\text { Fire wood } \\
\text { collection } \\
\text { Tiger Prawn } \\
\text { Seed collection } \\
\text { Crab collection } \\
\text { - Dependency } \\
\text { on natural } \\
\text { resources }\end{array}$ & $\begin{array}{l}\text { Environmental } \\
\text { Threat } \\
\text { - Damage of } \\
\text { mangrove } \\
\text { system } \\
\text { - Damage of } \\
\text { Tiger habitat } \\
\text { Overexploitation } \\
\text { of forest } \\
\text { resources } \\
\text { Overexploitation } \\
\text { of river } \\
\text { resources } \\
\text { - Human-animal } \\
\text { conflicts }\end{array}$ \\
\hline & 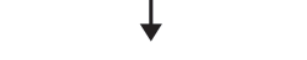 & $\downarrow$ \\
\hline Eco-P & $\begin{array}{l}\text { ic Manifesta } \\
\text { ted suicide }\end{array}$ & ticide \\
\hline $\begin{array}{l}\text { - Increased interpersona } \\
\text { mental health }\end{array}$ & cts and mala & ent-affecting \\
\hline $\begin{array}{l}\text { - Enhances supernatura } \\
\text { behavior }\end{array}$ & and influenc & Ith seeking \\
\hline \multicolumn{3}{|c|}{$\begin{array}{l}\text { - Reduction in eco-resources-fish, honey, other vegetations- } \\
\text { negative impact on forest based living }\end{array}$} \\
\hline \multicolumn{3}{|c|}{ - Straying of tiger and loss of both—tiger and human life } \\
\hline $\begin{array}{l}- \text { Hur } \\
\text { isol }\end{array}$ & orta & orbidity/so \\
\hline
\end{tabular}

\section{References:}

[1]. Convention on Biological Diversity (1992). United Nations. Available at: https://www.cbd.int/doc/legal/cbd-en.pdf

[2]. Newton J (2007). Wellbeing and the natural environment: A brief overview of the evidence. Available at: resolve.sustainablelifestyles.ac.uk/sites/default/files/JulieNewtonPaper.pdf

[3]. Ghosh A, Schmidt S, Fickert T, Nusser M (2015). The Indian Sundarban mangrove forests: History, utilization, conservation strategies and local perception. Diversity, 7: 149-169. 
[4]. Hajra R, Szabo S, Tessler Z, Ghosh T et al (2017). Unraveling the association between the impact of natural hazards and household poverty: evidence from the Indian Sundarban delta. Sustainability Sc , 1-12. DOI 10.1007/s11625-0160420-2

[5]. Hazra S, Das I, Samanta K, Bhadra T (2014). Impact of climate change in Sundarban area West Bengal, India. School of Oceanographic Studies. Earth Science and Climate Book. 9326/17.02.00.

[6]. Das S, Roy Choudhury M, Das S, Nagarajan M (2013). Integrated geospatial technologies for soil salinity assessment over South 24 PGS, West Bengal. Int. J. Geo Sci. \& Tech, 1(2): 41-85.

[7]. Debnath A (2013). Condition of agricultural productivity of Gosaba C.D. Block, South 24 Parganas, West Bengal, India after severe cyclone Aila. Int J Scientific \& Res Pub, 3(7): 1-4.

[8]. Bandopadhyay M, Basu R (2017) Crisis of fresh water in South 24 Parganas district, West Bengal: Causes and consequences. IOSR-J Humanities \& Soc Sciences, 22(6): 4-15.

[9]. Sánchez-Triana E, Ortolano L, Paul T (2018). Managing water-related risks in the West Bengal Sundarbans: policy alternatives and institutions, Int J Water Resources Development, 34 (1): 78-96.

[10]. Chowdhury AN, Banerjee S, Brahma A, Weiss MG (2007). Pesticide practices and suicide among farmers of Sundarban region. Food Nutrition Bulletin, 28: Suppl 2, S381-S391

[11].Hajra R, Ghosh T (2016). Migration pattern of Ghoramara Island of Indian Sundarban-identification of push and pull factors. Asian Academic Res J Soc Sc \& Humanities, 3(6): 186-195.

[12]. Chowdhury AN, Banerjee S, Brahma A, Biswas MK (2007). Pesticide poisoning in nonfatal, deliberate self-harm: A public health issue. Indian J Psychiatry, 49: 117-120.

[13]. Chowdhury AN, Banerjee S., Das S. et al (2005). Household survey of suicidal behaviour in a coastal village of Sundarban region, India. Int Med J (Japan), 12: 275-282.

[14]. Chowdhury AN, Banerjee S, Brahma A, et al (2010). A prospective study of suicidal behaviour in Sundarban delta, West Bengal, India. Nat Med J India, 23: 199-203.

[15]. Chowdhury AN, Dutta S, Sanyal D, et al. (2005). Community Psychiatric Clinics at Sundarban: A clinical and cultural experience. Ind J Pub Health, 49: 227-230.

[16]. Chowdhury AN, Banerjee S, Brahma A, Biswas MK (2008). A study of mortality and morbidity pattern of acute childhood poisoning cases admitted in Block Primary Health Centres of Sundarban, West Bengal. Ind J Pub Health, 52:40-42.

[17].Banerjee S, Chowdhury AN (2017). Globalisation of suicides by pesticide ingestion: An overview of developing nations with a focus on studies from an Indian delta region. In: R. White, S. Jain, D. Orr \& U. Read ed. Palgrave Handbook on Global Mental Health: Sociocultural Perspectives, University of Edinburgh, UK. Pp. 679-703.

[18].Hajra R, Ghosh T (2018). Agricultural productivity, household poverty and migration in the Indian Sundarban Delta. Elem Sci Anth, 6: 3. DOI: https://doi.org/10.1525/elementa.196

[19]. Gupta S, Sarkar G (2015). Climate change and economic adaptability of Indian Sunderban. Int J Innovation Sc \& Res, 4(8): 350-354.

[20]. Bhattacharyya R, Sanyal D, Dutta S, Ghosh M, Bhattacharyya S (2010). Sociodemographic comparison and impact of Aila: the supercyclone in Gosaba of West Bengal. Ind J Com Med, 35(3): 429-32.

[21].Unnikrishnan AS, Shankar D (2007). Are sea-level rise trends along the north Indian Ocean coasts consistent with global estimates? Glob Planet Change, 57(3-4):301-7.

[22]. Bera MK (2013). Adaptation with social vulnerabilities and flood disasters in Sundarban region: a study of Lodha tribes in Sundarban, West Bengal. Ind J Dalit Tribal Stud Action, 1(2):49-62.

[23]. Sánchez-Triana E, Paul T, Ortolano L, Ruitenebeek J (2014). Building Resilience for Sustainable Development of the Sundarbans. Strategy Report No. 88061-IN. The World Bank, Washington, DC. USA.

[24]. Banerjee S, Chowdhury AN, Schelling E, Weiss MG (2013). Household survey of pesticide practice, deliberate selfharm and suicide in the Sundarban region, India. BioMed Res Int, Article ID 949076 ( 9 pages), Hindawi Publishing Corporation.

[25]. Chowdhury AN, Chowdhury S, Chakraborty A (1999). Eco-stress, quality of life and mental health in Sundarban delta of India. Int Med J, 6(1):59-63.

[26].District Human Development Report, South 24 Parganas. Government of West Bengal. 2009. Available at: http://bplan.gov.in/HumanDev/./24\%20pgsSouth/TITEL_SOUTH\%202.

[27]. Chowdhury AN, Sarkar P, Das S, Maity T, Brahma A, Banerjee S. (2008). An ethnographic study of health system at Maisani Island: role of HCPs. J Indian Anthropol Soc, 42:165-76.

[28]. Chowdhury AN, Jadav S (2012). Ecopsychiatry: Culture, mental health and ecology with special reference to India. In, Textbook on Community Psychiatry in India (Eds. BS Chavan, N Gupta, P Arun, AK Sidana, S Jadhav), pp 521541, Jaypeebrothers: New Delhi.

[29]. Chattopadhyay SS (2001).Terror in Sundarban. Frontline, 18(15). Available at: https://www.frontline.in/static/html/fl1815/18150390.htm

[30]. Bandopadhyay S (2015). Sundarbans -a lucrative hunting ground for criminal gangs from B'desh. Hindustan Times. Available at: https://www.hindustantimes.com/india/sunderbans-a-lucrative-hunting-ground-for-criminal-gangs-fromb-desh/story-mCdAXWr leuMcYnvJzk SniL .html

[31].Sarkar RM (2009). Sundarban fishermen in the World Heritage setting: A community striving in the mystic mangrove ecosystem. New Delhi, India: Serial Publications. 
[32]. Chowdhury AN, Monda R, Brahma A, Biswas M.K (2008). Ecopsychiatry and environmental conservation: Study from Sundarban delta, India. Environmental Health Insight, 2:61-76.

[33]. Samanta A, Chakraborti K, Bandopadhyay M, Sengupta R (2013). Moule, honey collectors of Sundarbans and their ITKs. Am J Adv Med Sci,1(2):1-6.

[34]. Vidal J (2008). There are many tiger widows here. Available at: http://www.theguardian.com/environment/2008/sep/25/conservation.climatechange.

[35].Sahu S, Das B, Chowdhury S, Das G, Das A, Arefin B 2013). Economic analysis of mud crab fattening in Gosaba block of deltaic Sundarban in West Bengal. Environ Ecol, 31(1 A):273-7.

[36]. Times of India (2009). Crab collector lifted by tiger. Available at: http://articles.timesofindia.indiatimes.com/2009-09-08/flora-fauna/28077664_1_crabs-tiger-sundarbans.

[37].Indic Knowledge Operations Network, Kolkata (2007). Pilot livelihood assessment study of prawn fingerling catchers in the Sundarbans - a report. Available at: http://towner.in/yahoo_site_admin/assets/docs/SDB_rep_comb_final.145161006.pdf.

[38]. Society for Direct Initiative for Social \& Health Action (2006). Corporate abuse in Indian Sundarban - a DISHA study. Available at: http://www.dishaearth.org/Corporate\%20Abuse\%20in\%20Sunderban.pdf.

[39]. Chowdhury AN, Shasmal, RK, Ramakrishna J, Weiss MG (2001). Eco-stress of human-animal conflicts in the Sundarban Delta of West Bengal, India. Eastern Anthropologist, 54: 35-50.

[40].Das CS, Jana R (2018). Human-crocodile conflict in the Indian Sundarban: an analysis of spatio-temporal incidences in relation to people's livelihood. Oryx, 52(4): 661-668.

[41].Das P, Das A, Roy S (2016). Shrimp fry (meen) farmers of Sundarban mangrove forest (India): A tale of ecological damage and economic hardship. Int J Agri \& Food Res, 5(2):28-41.

[42]. Chowdhury AN, Mondal R, Brahma A, Biswas MK (2016). Eco-psycho-social aspects of Human- Tiger conflict: An ethnographic study of Tiger-widows of Sundarban Delta, India. Environmental Health Insight, 10, 1-29.

[43]. Chowdhury AN, Mondal R, Biswas MK, Brahma A (2012). Post Traumatic Eco-Stress Disorders (PTESD): A qualitative study from Sundarban Delta, India.. In, "Mental Disorders: Theoretical and Empirical Perspectives"(Eds.Robert Woolfolk and Lesley Allen, InTeOp, 309-347.

[44]. Chowdhury AN, Ramkrishna J. Chakraborty A, Weiss MG(2006). Cultural context and impact of alcohol use in Sundarban delta, West Bengal, India. Soc Sc \& Med, 63, 722-731.

[45]. Mahadevia M K, Vikas M (2012). Climate change- impact on the Sundarbans: A case study. Int Scientific J Environmental Sc. 2: 7-14.

[46].Gupta J (2018). Rising sea swamps island along Bengal coast. India Climate Dialogue. Available at: http://indiaclimatedialogue.net/2018/01/15/rising-sea-swamps-island-along-bengal-coast/

[47]. Singh SS (2017). Climate change impact: Sundarbans steadily losing its famed mangroves. Available at: https://www.thehindu.com/sci-tech/energy-and-environment/climate-change-impact-sunderbans-steadily-losing-itsfamed-mangroves/article19195229.ece

[48].Haque M Z, Hasan RMI, Rahim, SA, Abdullah MP et al (2015). Behavioral change due to climate change effects accelerate tiger human conflicts: A study on Sundarbans mangrove forests, Bangladesh. Int J Conservation Sc, 6(4), 669-684.

[49].New Scientist (2008). Climate change is driving increase in tiger attacks. Available at: https://www.newscientist.com/article/dn15000-climate-change-is-driving-increase-in-tiger-attacks/

[50]. Daszak P, Cunningham AA, Hyatt AD (2000). Wildlife ecology — emerging infectious diseases of wildlife - threats to biodiversity and human health: Science, 287(5452): 443-449.

[51].Berry HL, Bowen K, Kiellstorm T (2010). Climate change and mental health: a casual pathways framework. Int $J$ Public Health, 55(2): 123-132.

[52].Nurse J, Basher D, Bone A, Bird W (2010). An ecological approach to promoting population mental health and wellbeing- a response to the challenge of climate change. Perspectives in Pub Health, 130(1): 27-33.

[53].Danda A (2010). Sundarbans: Future imperfect climate adaptation report. WWF. Available at: http://www.indiaenvironmentportal.org.in/content/327139/sundarbans-future-imperfect-climate-adaptation-report/

[54].Jalis A (2008). Bonobibi: bridging worlds. Ind Folklore Serial,.28:6-8.

[55].Bhargava M (2008). Forest, wild beasts and supernatural powers: a folk tale from Sundarbans. Ind Folklife Serial, 28:10-11.

[56]. Chowdhury AN, Mondal R, Brahma A, Biswas MK (2016). Stigma of tiger attack: Study of tiger-widows from Sundarban Delta, India. Ind J Psychiatry, 58:12-19.

[57].Dasgupta A, Guchhait SK (2013). A comparison of normative values for reverine and non-reverine communities of the Indian Sundarbans: an exploration into sociological aspect of the residents of Malta river. Int J Human Soc Sci Invent, 2(12):42-7.

[58].Jalais A (2010). Forest of Tigers. People, Politics and Environment in the Sundarbans. New Delhi, India: Routledge; pp.146-212.

[59].Niyogi T (2009). Tiger Cult of the Sundarvans. Calcutta,India: Anthropological Survey of India; 88-95.

[60]. Banerjee M (2014). ECO tourisms in Sundarbans... A life line for local people and ecology. Int J Sc \& Res. 3(11): 761 771. 
[61]. Wood ME (1999) The Ecotourism Society-An International NGO committed to sustainable development. Tourism Recreation Res, 24 (2), 119-123.

[62]. Chowdhury JK, Yale MF, Ahmed JU (2014). Tourism: Emerging as a threat to Sundarban ecosystem. Available at: www.theguardianbd.com/tourism-emerging-as-a-threat-to-sundarban-ecosystem/

[63]. Karanth K, DeFries R, Srivathsa A, Sankaraman V (2012). Wildlife tourist in India's emerging economy: potential for a conservation constituency? Oryx, 46(3): 382-390.

[64].Das R, Santra SC (2014). Integrated tourism planning in protected area of Sundarban National Park, India. $J$ Environment \& Sociobiology, 11(2): 211-218

[65].Guha I, Ghosh S (2007). Does tourism contribute to local livelihoods? A case study of tourism, poverty and conservation in the Indian Sundarbans. SANDEE working paper No. 26-07. Available at: https://opendocs.ids.ac.uk/opendocs/bitstream/handle/123456789/4368/750_PUB_working_paper_26.pdf;jsessionid=8 8248A6217312964313E5AE2297C50A9?sequence=1

[66].Saha K (2017). Heritage of the Sundarban: Connecting nature to culture. J World Heritage Studies, Special Issue, 6267. http://doi.org/10.15068/00148451

[67]. Shah MAR (2011). Towards ecotourism: issues of current tourism practices in the Sundarban mangrove forest of Bangladesh. Paper presented in Peace, Environment and Tourism Conference, 20-21 September, 2011, Pokhara, Nepal.

[68].Chowdhury AN, Mondal R, Biswas MK, Brahma A (2014). Culture and stigma: Ethnographic case studies of tigerwidows of Sundarban delta, India. World Cul Psyciat Res Rev, 9(3): 99-122. 